\title{
Efek eugenol terhadap jumlah sel inflamasi pada pulpa gigi molar tikus Sprague Dawley
}

\author{
Raras Ajeng Enggardipta*, Tetiana Haniastuti ${ }^{* *}$, Juni Handajani ${ }^{* *}$ \\ *Departemen Konservasi Gigi, Fakultas Kedokteran Gigi, Universitas Gadjah Mada, Yogyakarta, Indonesia \\ **Departemen Biologi Mulut, Fakultas Kedokteran Gigi, Universitas Gadjah Mada, Yogyakarta, Indonesia \\ JI Denta No 1 Sekip Utara, Yogyakarta, Indonesia; e-mail: rarasajeng@ugm.ac.id
}

Submisi: 12 Januari 2016; Penerimaan: 12 Juni 2016

\begin{abstract}
ABSTRAK
Penelitian ini bertujuan untuk mengetahui pengaruh eugenol terhadap jumlah sel inflamasi (netrofil, makrofag dan limfosit) pada pulpa gigi terinflamasi. Tiga puluh ekor tikus Sprague Dawley jantan berumur 3-4 bulan dengan berat badan 300-350 g dibagi secara acak dalam 2 kelompok yaitu perlakuan dan kontrol. Tikus diinjeksi ketamine $\mathrm{HCl}$ i.m. $(0,1$ $\mathrm{ml} / 100$ gram BB) sebelum dilakukan preparasi kavitas pada permukaan oklusal gigi molar satu rahang atas. Preparasi kavitas dibuat dengan menggunakan bur bulat No.010 hingga kedalaman pulpa. Pada dasar kavitas kelompok perlakuan (15 ekor) diberi eugenol dan kelompok kontrol (15 ekor) diberi akuades, kemudian kavitas ditumpat sementara. Tiga ekor tikus dari masing-masing kelompok dikorbankan pada 1, 3, 5, 7 dan 14 hari pasca preparasi kavitas. Tikus diinjeksi ketamine $\mathrm{HCl}$ i.m. $(0,1 \mathrm{ml} / 100$ gram BB) pada paha kemudian jaringan diambil, diproses secara histologis dan dicat dengan hematoxylin eosin. Data jumlah sel inflamasi (netrofil, makrofag dan limfosit) dianalisis dengan Two Way Anova. Hasil penelitian menunjukkan rerata jumlah infiltrasi sel inflamasi kelompok perlakuan lebih rendah dibandingkan kontrol dan berbeda bermakna $(p<0,05)$. Kesimpulan dari penelitian ini adalah pemberian eugenol pada pulpa gigi tikus Sprague Dawley yang mengalami inflamasi dapat menurunkan jumlah sel inflamasi (netrofil, makrofag dan limfosit).
\end{abstract}

Kata kunci: eugenol, pulpitis, sel inflamasi

\begin{abstract}
Inflammatory cells infiltration after eugenol administration in Sprague Dawley rat's molars. The purpose of this study was to determine effect of eugenol on inflammatory cells infiltration (neutrophils, macrophages and lymphocytes) in the inflamed dental pulp. Thirty male Sprague Dawley rats aged 3-4 months and weighed 300-350 $g$ were randomly divided into 2 groups: treated and control groups. Rats were injected with ketamine $\mathrm{HCl}$ i.m. $(0.1 \mathrm{ml}$ 1100 grams BW) before cavity preparation at occlusal surface of the upper molars. Cavity preparation was made using a round bur No.010 to pulp perforation. At the cavity base of treated group, 15 rats were given eugenol and of control group 15 rats were given aquadest, before filled with temporary filling. Three rats from each group were sacrificed at 1, 3, 5, 7 and 14 days after the cavity preparation. Rats were injected with ketamine $\mathrm{HCl}$ im $(0.1 \mathrm{ml} / 100 \mathrm{~g} \mathrm{BW})$ on the thigh then tissues were collected for histological process and stained using haematoxylin eosin. The number of inflammatory cells (neutrophils, macrophages and lymphocytes) was analysed by Two-Way Anova. The result of the study showed number of inflammatory cells infiltration of treated group was lower than control and showed significant differences between groups $(p<0.05)$. The conclusion from this study is eugenol administration in Sprague Dawley rats's inflamed dental pulp can reduce the number of inflammatory cells (neutrophils, macrophages and lymphocytes).
\end{abstract}

Keywords: eugenol, pulpitis, inflammatory cells

\section{PENDAHULUAN}

Pulpitis merupakan peradangan pulpa sebagai reaksi jaringan ikat vaskuler yang sangat penting terhadap cedera. ${ }^{1}$ Pulpitis mirip dengan inflamasi pada jaringan ikat di bagian tubuh lainnya. Sel-sel yang berhubungan dengan reaksi inflamasi pada jaringan ikat adalah leukosit polimorfonuklear dan leukosit mononuklear termasuk makrofag dan limfosit. ${ }^{2}$

Pulpitis dapat diklasifikasikan sebagai pulpitis reversibel, ireversibel dan hiperplastik. Pulpitis ireversibel seringkali merupakan akibat atau perkembangan dari pulpitis reversible ${ }^{1}$ yang ditandai dengan nyeri spontan yang intermiten, ${ }^{1}$ atau nyeri akut dan intens yang sulit dikontrol dengan obat penghilang rasa sakit, ${ }^{3}$ sehingga membutuhkan penanganan segera. Dahulu, penanganan rasa nyeri pada pasien pulpitis dengan cara devitalisasi pulpa kemudian ditumpat sementara. Hal ini dilakukan sebelum pasien mendapatkan penanganan dokter gigi spesialis. ${ }^{3}$ 
Penanganan rasa nyeri dengan mematikan saraf gigi dapat menggunakan bahan arsenik trioksida. ${ }^{4}$ Penggunaan arsenik trioksida di dalam perawatan gigi pertama kali dilakukan oleh Haly Abbas pada tahun 1492. Bahan tersebut digunakan untuk mematikan pulpa gigi terinflamasi. ${ }^{4}$ Menurut Garip dkk., ${ }^{5}$ devitalisai pulpa gigi dengan bahan arsenik trioksida masih digunakan dalam perawatan saluran akar di beberapa daerah.

Penggunaan arsenik trioksida diketahui bersifat toksik bagi jaringan vital. Kebocoran berkepanjangan dari arsenik trioksida dapat menyebabkan kerusakan jaringan periodontal yang parah. ${ }^{6}$ Jika bahan devitalisai berdifusi dari kavitas, bahan tersebut menyebabkan nekrosis gingiva dan tulang, yang dapat menyebabkan osteomyelitis rahang. ${ }^{6,7}$

Dengan mempertimbangkan bahaya penggunaan arsenik trioksida, DepKes $\mathrm{Rl}^{8}$ menyarankan bahwa penatalaksanaan pasien dengan pulpitis ireversibel berupa pembersihan pada lubang gigi dengan menggunakan ekskavator dan water syringe, lalu dikeringkan dengan kapas dan kavitas diberi pelet kapas yang ditetesi eugenol. Menurut Tronstad, ${ }^{9}$ pemberian medikamen anodyne seperti eugenol dapat meringankan gejala pulpitis ireversibel hingga 92\%. Penggunaan eugenol dilakukan sebagai perawatan sementara bagi pasien pulpitis ireversibel sebelum mendapatkan perawatan saluran akar dari dokter gigi spesialis.

Eugenol (4-allyl-2-methoxyphenol) digunakan secara luas di dalam bidang kedokteran gigi karena aktivitas antiinflamasi dan analgesiknya, serta kemampuannya meredakan sakit gigi yang berasal dari berbagai sumber, termasuk pulpitis. ${ }^{10,11}$ Eugenol diketahui memiliki aktivitas antiinflamasi yaitu menghambat sitokin proinflamasi seperti IL-1 dan TNF- $\alpha$ yang menyebabkan vasodilatasi pembuluh darah dengan cara merangsang endotel untuk memproduksi faktor kemotaktik yang berperan dalam proses rolling dan adhesi leukosit. ${ }^{12}$ Selain menghambat IL-1 dan TNF- $\alpha$ eugenol diketahui dapat menghambat IFN- $\gamma$ yang berperan dalam diferensiasi monosit menjadi makrofag. ${ }^{13}$ Penelitian ini bertujuan untuk mengetahui pengaruh eugenol terhadap jumlah sel inflamasi pada pulpa gigi tikus Sprague Dawley yang terinflamasi.

\section{METODE PENELITIAN}

Penelitian ini telah mendapatkan persetujuan dari Komisi Etik Fakultas Kedokteran Gigi Universitas Gadjah Mada. Tiga puluh ekor tikus Sprague Dawley jantan dibagi menjadi 2 kelompok. Tiap kelompok terdiri atas 15 ekor dengan pembagian 3 ekor tikus untuk masing-masing kelompok hari pengamatan $(1,3,5,7$, dan 14 hari setelah perlakuan).

\section{Perlakuan hewan coba}

Sebelum dilakukan preparasi kavitas, tikus dianestesi secara intramuskular dengan ketamin $\mathrm{HCl} 0,1 \mathrm{ml} / 100$ gram berat badan. Gigi molar satu rahang atas dipreparasi pada permukaan oklusal menggunakan diamond round bur No. 010 (Edenta, Switzerland) dengan kedalaman hingga mencapai pulpa. Pada kelompok perlakuan, eugenol diaplikasikan pada dasar kavitas. Sebelumnya, eugenol diteteskan pada cotton pellet, diletakkan pada kapas dan ditekan dengan anak timbangan, kemudian kavitas ditumpat dengan tumpatan sementara. Akuades diteteskan pada cotton pellet, diletakkan pada kapas dan ditekan dengan anak timbangan. Cotton pellet yang mengandung akuades diaplikasikan pada dasar kavitas untuk kelompok kontrol. Prosedur selanjutnya ditumpat dengan tumpatan sementara.

\section{Pembuatan preparat histologis}

Pada hari ke-1, - - $,-5,-7$ dan -14 setelah perlakuan, tikus dikorbankan dengan terlebih dulu dianestesi ketamine $\mathrm{HCl} 0,1 \mathrm{ml} / 100$ gram berat badan secara intramuskular pada paha. Setelah tikus menurun kesadarannya, dilakukan perfusi transkardial pada tikus. Selanjutnya dilakukan pengambilan rahang pada bagian gigi molar kemudian difiksasi dengan buffered formalin 10\% dan didekalsifikasi menggunakan EDTA $10 \% \mathrm{pH}$ 7,4. Spesimen kemudian didehidrasi dengan cara direndam dalam alkohol bertingkat dilanjutkan dengan bahan penjernih. Spesimen dimasukkan ke dalam xylol-parafin (1:1) kemudian dilanjutkan dengan parafin murni I, parafin murni II, parafin murni III masing-masing selama 60 menit. Parafin cair dituang ke dalam kotak sampai penuh dan dijaga jangan 
sampai ada gelembung udara di dalam blok parafin, kemudian spesimen diambil dengan menggunakan pinset lancip dan dimasukkan ke dalam blok parafin. Letak jaringan diatur sedemikian rupa sehingga pada saat dipotong akan diperoleh potongan membujur. Blok parafin didiamkan sampai mengeras sebelum dipotong. Selanjutnya, blok parafin dipotong setebal $6 \mu \mathrm{m}$ untuk dicat hematoksilin eosin.

\section{Pengamatan dan analisis data}

Penghitungan jumlah sel inflamasi (sel netrofil, makrofag dan limfosit) dilakukan pada area di bawah preparasi kavitas dengan 3 lapang pandang yang berbeda. Data yang diperoleh dari hasil perhitungan jumlah sel inflamasi adalah berskala rasio diuji homogenitas dan normalitas selanjutnya dianalisis menggunakan uji statistik Anava dua jalur.

\section{HASIL PENELITIAN}

Netrofil dengan pengecatan HE akan tampak granular mempunyai nukleus yang terdiri dari dua lobus atau lebih, sedangkan makrofag secara mikroskopis tampak sebagai sel mononuklear, bulat dengan inti lonjong atau berbentuk ginjal yang terletak eksentris dengan sitoplasma yang mengandung granular dengan kepadatan sedang. Limfosit dengan pengecatan HE akan tampak sebagai sel berbentuk bulat, kecil dengan nukleus berlekuk dan sedikit granular pada sitoplasmanya. ${ }^{16}$

Hasil pengamatan histologis (Gambar 1) menunjukkan bahwa pada hari ke-1 setelah pemberian eugenol (perlakuan) tampak infiltrasi sel inflamasi pada area di bawah jejas. Pada kelompok yang diberi akuades (kontrol), jumlah sel

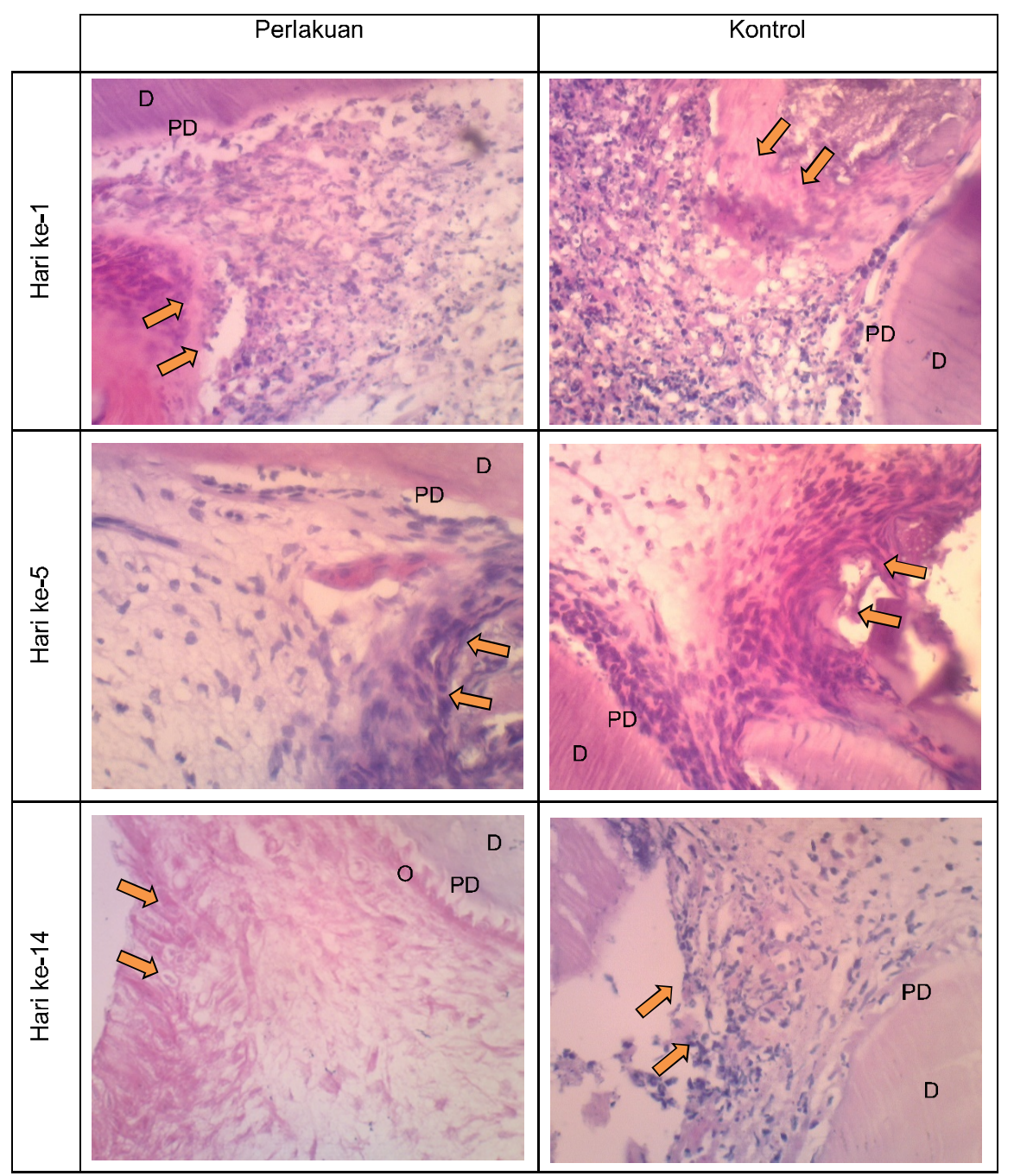

Gambar 1. Gambaran respon inflamasi pulpa setelah pemberian eugenol dibandingkan kontrol pada hari ke-1, hari ke-5 dan hari ke-14 (HE; 400x). Infiltrasi sel inflamasi pada perlakuan tampak lebih sedikit dibandingkan kontrol. Inflamasi menurun seiring bertambahnya waktu pengamatan. $\mathrm{D}=$ dentin, $\mathrm{PD}=$ predentin, $\mathrm{O}=$ odontoblas, $\boldsymbol{\mathbf { D }}=$ arah jejas. 
inflamasi lebih padat dibandingkan pada kelompok perlakuan. Pada kedua kelompok tidak ditemukan lapisan odontoblas pada area di bawah jejas. Pada hari ke-5 setelah perlakuan, pada kelompok yang diberi eugenol menunjukkan inflamasi sudah mereda ditandai dengan berkurangnya infiltrasi sel inflamasi. Pada kelompok kontrol inflamasi juga mereda namun jumlah sel inflamasi lebih padat dibandingkan kelompok perlakuan. Pada hari ke14 sudah tidak tampak adanya inflamasi pada area di bawah jejas pada perlakuan, sedangkan pada kontrol masih tampak sedikit sel inflamasi.

Hasil perhitungan jumlah netrofil (Tabel 1) menunjukkan bahwa pada hari ke-1 netrofil banyak ditemukan. Rerata jumlah netrofil pada kedua kelompok menurun seiring bertambahnya hari pengamatan. Rerata jumlah netrofil pada kelompok perlakuan lebih rendah dibandingkan dengan rerata jumlah netrofil kelompok kontrol. Pada kedua kelompok, infiltrasi makrofag sudah tampak pada hari ke-1, infiltrasi makrofag banyak pada area di bawah jejas. Infiltrasi makrofag semakin meningkat pada hari ke-3 dan paling banyak ditemukan pada hari ke-5. Pada hari ke-7 dan hari ke-14 jumlah infiltrasi makrofag semakin menurun. Rerata jumlah makrofag pada kelompok perlakuan lebih sedikit dibandingkan dengan kelompok kontrol pada setiap waktu pengamatan. Jumlah limfosit meningkat mulai hari ke-1 dan mencapai puncak pada hari ke-5. Pada hari ke-7 dan ke-14 jumlah limfosit semakin berkurang. Jumlah limfosit pada kelompok perlakuan eugenol lebih sedikit dibandingkan kelompok kontrol.

Tabel 1. Rerata dan simpangan baku sel inflamasi

\begin{tabular}{clccc}
\hline & & \multicolumn{3}{c}{ Rerata dan Simpangan Baku } \\
\hline Hari & Kelompok & \multicolumn{1}{c}{ Netrofil } & Makrofag & Limfosit \\
\hline 1 & Perlakuan & $6,67 \pm 0,577$ & $2,33 \pm 0,577$ & $1,00 \pm 0,000$ \\
& Kontrol & $8,00 \pm 0,000$ & $3,00 \pm 0,000$ & $1,33 \pm 0,577$ \\
\multirow{2}{*}{3} & Perlakuan & $6,33 \pm 0,577$ & $2,63 \pm 0,577$ & $1,00 \pm 0,000$ \\
& Kontrol & $6,67 \pm 0,577$ & $3,33 \pm 0,577$ & $2,00 \pm 1,000$ \\
\multirow{2}{*}{5} & Perlakuan & $3,67 \pm 0,577$ & $3,67 \pm 0,577$ & $2,00 \pm 1,000$ \\
& Kontrol & $4,67 \pm 0,577$ & $4,00 \pm 0,000$ & $3,00 \pm 0,000$ \\
7 & Perlakuan & $3,67 \pm 0,577$ & $3,33 \pm 0,577$ & $1,33 \pm 0,577$ \\
& Kontrol & $3,67 \pm 0,577$ & $4,33 \pm 0,577$ & $2,67 \pm 0,577$ \\
14 & Perlakuan & $1,67 \pm 0,577$ & $1,33 \pm 0,577$ & $1,33 \pm 0,577$ \\
& Kontrol & $2,00 \pm 0,000$ & $1,67 \pm 0,577$ & $2,00 \pm 0,000$ \\
\hline
\end{tabular}

Hasil uji normalitas dan homogenitas menunjukkan bahwa data terdistribusi secara normal dan homogen sehingga memenuhi syarat untuk dilakukan uji parametrik menggunakan Anava dua jalur. Rangkuman hasil uji Anava dua jalur dapat dilihat pada Tabel 2. Hasil uji Anava dua jalur menunjukkan bahwa terdapat perbedaan yang bermakna jumlah netrofil antar kelompok $(p<0,05)$. Hal ini berarti bahwa perlakuan, waktu pengamatan dan interaksi antara perlakuan dan waktu pengamatan berpengaruh signifikan terhadap jumlah infiltrasi sel inflamasi.

Uji LSD dilakukan untuk mengetahui signifikansi perbedaan jumlah sel inflamasi antara masing-masing kelompok (Tabel 3). Hasil uji LSD menunjukkan bahwa terdapat perbedaan jumlah netrofil yang bermakna $(p<0,05)$ antara kelompok perlakuan bila dibandingkan dengan kelompok kontrol pada hari ke-1, hari ke-3, dan hari ke-5, sedangkan pada hari ke-7 dan hari ke-14 tidak terdapat perbedaan jumlah netrofil yang bermakna antara kedua kelompok tersebut. Perbedaan jumlah makrofag bermakna $(p<0,05)$ antara masing-masing kelompok pada setiap waktu pengamatan yaitu hari ke-1 sampai dengan hari ke-14. Hasil uji LSD menunjukkan perbedaan jumlah limfosit yang bermakna $(p<0,05)$ antara kelompok perlakuan dan kelompok kontrol pada hari ke-3 dan hari ke-5, sedangkan pada hari ke-1, hari ke-7 dan hari ke-14 tidak terdapat perbedaan jumlah limfosit yang bermakna.

Tabel 2. Rangkuman Hasil Uji Anava Dua Jalur Sel Inflamasi

\begin{tabular}{|c|c|c|c|c|c|c|c|}
\hline & & \multicolumn{2}{|c|}{ Netrofil } & \multicolumn{2}{|c|}{ Makrofag } & \multicolumn{2}{|c|}{ Limfosit } \\
\hline & & $\mathrm{F}$ & $\mathrm{p}$ & $\mathrm{F}$ & $\mathrm{p}$ & $\mathrm{F}$ & $\mathrm{p}$ \\
\hline \multicolumn{2}{|c|}{ Perlakuan } & 15,36 & $0,00^{*}$ & 8,10 & $0,01^{*}$ & 19,69 & $0,02^{*}$ \\
\hline \multicolumn{2}{|c|}{ Waktu } & 52,59 & $0,00^{*}$ & 26,65 & $0,00^{*}$ & 6,80 & $0,00^{*}$ \\
\hline \multicolumn{2}{|c|}{ Perlakuan-Waktu } & 3,35 & $0,00^{*}$ & 1,35 & $0,04^{*}$ & 1,42 & $0,00^{*}$ \\
\hline \multicolumn{8}{|c|}{ Tabel 3. Hasil Uji LSD Sel Inflamasi } \\
\hline & & & \multicolumn{5}{|c|}{ Nilai LSD } \\
\hline Hari & \multicolumn{2}{|l|}{ Kelompok } & \multicolumn{2}{|c|}{ Netrofil } & \multicolumn{2}{|c|}{ Makrofag } & Limfosit \\
\hline 1 & \multicolumn{2}{|c|}{ Perlakuan-Kontrol } & \multicolumn{2}{|c|}{$0,00^{*}$} & $0,00^{*}$ & \multicolumn{2}{|c|}{1,00} \\
\hline 3 & \multicolumn{2}{|c|}{ Perlakuan-Kontrol } & \multicolumn{2}{|c|}{$0,00^{*}$} & $0,00^{*}$ & \multicolumn{2}{|c|}{$0,00^{*}$} \\
\hline 5 & \multicolumn{2}{|c|}{ Perlakuan-Kontrol } & \multicolumn{2}{|c|}{$0,00^{*}$} & $0,00^{*}$ & \multicolumn{2}{|c|}{$0,00^{*}$} \\
\hline 7 & \multicolumn{2}{|c|}{ Perlakuan-Kontrol } & \multicolumn{2}{|c|}{0,19} & $0,00^{*}$ & \multicolumn{2}{|c|}{0,22} \\
\hline 14 & \multicolumn{2}{|c|}{ Perlakuan-Kontrol } & \multicolumn{2}{|c|}{0,05} & $0,00^{*}$ & \multicolumn{2}{|c|}{1,00} \\
\hline
\end{tabular}




\section{PEMBAHASAN}

Hasil penelitian ini menunjukkan bahwa terjadi penurunan infiltrasi sel inflamasi setelah pemberian eugenol pada pulpa gigi tikus yang terinflamasi. Penurunan jumlah infiltrasi sel inflamasi (netrofil, makrofag dan limfosit) pada kelompok perlakuan diduga disebabkan oleh efek antiinflamasi eugenol. ${ }^{12}$ Hasil penelitian ini menunjukkan bahwa pada gigi tikus Sprague Dawley setelah dibur hingga kedalaman mencapai pulpa, tampak infiltrasi sel inflamasi pada area di bawah jejas. Selain tampak tanda-tanda inflamasi, odontoblas pada area di bawah jejas tidak dapat diamati. Hal ini sesuai penjelasan Ingle dkk. ${ }^{14}$ dan Walton dan Torabinejad ${ }^{1}$ bahwa jaringan pulpa dapat teriritasi secara mekanik yaitu preparasi kavitas yang dalam sehingga dapat merusak odontoblas. Pada penelitian ini preparasi kavitas dilakukan dengan menggunakan instrumen putar kecepatan rendah tanpa semprotan air pendingin. Hal ini kemungkinan menyebabkan inflamasi pada pulpa sesuai penjelasan Walton dan Torabinejad ${ }^{1}$ bahwa pembuangan struktur gigi tanpa pendinginan yang memadai juga dapat mengiritasi pulpa.

Pada hari ke-1 terjadi infiltrasi sel inflamasi terutama netrofil pada kedua kelompok. Netrofil merupakan sel leukosit yang pertama kali migrasi ke jaringan/lokasi jejas. ${ }^{15}$ Sel ini dominan dalam 24-36 jam setelah terjadi jejas, berfungsi untuk menghilangkan iritan serta jaringan yang rusak melalui proses fagositosis. ${ }^{16,17}$ Gesekan dan panas yang ditimbulkan oleh penggunaan instrumen putar pada saat diakukan preparasi kavitas pada penelitian ini menyebabkan peningkatan nitric oxide (NO) pada sel odontoblas. ${ }^{17}$ Nitric oxide merupakan radikal bebas yang dapat menyebabkan vasodilatasi pembuluh darah sehingga sel inflamasi akan bermigrasi menuju jaringan. ${ }^{18}$ Vasodilatasi pembuluh darah meningkatkan permeabilitas pembuluh darah sehingga menyebabkan migrasi sel netrofil melalui dinding endotel menuju tempat jejas. Rekruitmen netrofil ke area jejas diinisiasi juga oleh perubahan permukaan endothelium yang disebabkan oleh stimulasi mediator inflamasi yaitu histamin, cysteinyl-leukotrienes, dan sitokin yang dihasilkan oleh leukosit tissue-resident ketika terjadi jejas. ${ }^{19}$ Sitokin proinflamasi yang dihasilkan oleh leukosit tissue-resident antara lain IL-1 dan TNF- $\alpha$ berfungsi menginduksi vasodilatasi pembuluh darah sehingga terjadi peningkatan permeabilitas pembuluh darah. Di dalam pembuluh darah, IL-1 dan TNF- $\alpha$ menginduksi sel endotel untuk mensekresikan E-selektin dan intercellular adhesion molecule-1 (ICAM-1). Intercellular adhesion molecule-1 akan berikatan dengan integrin leukosit yang berfungsi dalam proses adhesi leukosit yang kemudian berdiapedesis dari pembuluh darah menuju jaringan. ${ }^{20}$ Saat terjadi jejas, selain melepaskan NO, odontoblas juga melepaskan sitokin inflamasi IL-8 yang berfungsi sebagai kemoatraktan, sehingga netrofil bermigrasi ke area jejas. ${ }^{21}$

Rerata jumlah netrofil pada kelompok perlakuan lebih sedikit dibandingkan kelompok kontrol pada hari ke-1, hari ke-3 dan hari ke-5. Hal ini kemungkinan disebabkan eugenol yang memliki aktivitas antiinflamasi dengan cara menghambat produksi NO, IL-1 dan TNF- $\alpha .{ }^{14,22,23}$ Penghambatan produksi NO, IL-1 dan TNF- $\alpha$ menyebabkan vasodilatasi pembuluh darah menurun sehingga netrofil yang bermigrasi ke jaringan jumlahnya juga akan menurun. Selain itu dengan dihambatnya produksi IL-1 dan TNF- $\alpha$ jumlah netrofil yang migrasi ke area jejas akan berkurang.

Hasil penelitian ini menunjukkan bahwa jumlah netrofil menurun seiring waktu pengamatan. Hal ini disebabkan netrofil mengalami apoptosis yaitu kematian sel terprogram setelah menyelesaikan tugasnya pada area jejas. ${ }^{24}$ Pada hari ke-7 dan hari ke-14 diketahui bahwa tidak terdapat perbedaan jumlah netrofil yang bermakna antara kelompok perlakuan dan kelompok kontrol. Hal ini diduga disebabkan fase inflamasi mulai berakhir dan sudah memasuki fase proliferasi.

Sel inflamasi lainnya yang diamati pada penelitian ini adalah makrofag. Hasil penelitian ini menunjukkan bahwa pada kedua kelompok sudah ditemukan makrofag pada area di bawah jejas pada hari ke-1. Hal ini disebabkan pada jaringan terdapat makrofag tissue-residentyang dapatmensekresikan sitokin TNF- $\alpha$, IL-6, IL-12 dan IL-1 $\beta$ pada saat terjadi jejas. ${ }^{22}$ Dua sampai tiga hari setelah terjadi jejas, monosit di dalam pembuluh darah bermigrasi 
ke jaringan dan berdiferensiasi menjadi makrofag yang berfungsi melanjutkan proses fagositosis yang dilakukan oleh netrofil. ${ }^{23,25,26}$ Monosit dijumpai dalam darah sebagai prekursor sistem fagosit mononukleus yang baru dibentuk. Rekruitmen makrofag ke area jejas dimulai dari migrasi monosit dari pembuluh darah. Adanya jejas menyebabkan sel endotel melepaskan sitokin proinflamasi (CCL-2, IL-6, IL-8) yang menginduksi kemotaksis monosit. Faktor lain yang merekrut monosit ke area jejas adalah TGF- $\beta$, PDGF, dan VEGF, dan TGF- $\alpha{ }^{26}$ Setelah memasuki area jejas, sitokin seperti IFN-y, IL-4, IL-10, dan IL-13 menyebabkan monosit berdiferensiasi menjadi makrofag. ${ }^{27,28}$ Setelah menerobos dinding kapiler dan masuk ke jaringan ikat, maka monosit berkembang menjadi makrofag. Makrofag mempunyai kemampuan untuk memfagositosis debris, bakteri dan netrofil yang mengalami apoptosis pada area jejas. ${ }^{26}$

Pada hari ke-3 tampak jumlah sel makrofag mulai meningkat dan ditemukan paling banyak pada hari ke-5, hal ini sesuai dengan penjelasan Regan dan Barbul ${ }^{29}$ yang menyebutkan bahwa makrofag yang berasal dari monosit di dalam pembuluh darah dapat diamati di jaringan 48-96 jam setelah jejas, dan mencapai puncaknya pada hari ke-4. ${ }^{17}$ Pada penelitian ini, tidak dilakukan pengamatan pada hari ke-4 namun pengamatan dilakukan pada hari ke-5 setelah jejas sehingga jumlah makrofag masih tampak berada di puncak.

Pada hari ke-7 dan ke-14 setelah jejas, jumlah makrofag mulai menurun. Hal ini karena fase inflamasi sudah berakhir dan memasuki fase proliferasi, sesuai dengan penjelasan Fitridge dan Thompson ${ }^{27}$ yang menyebutkan bahwa berkurangnya makrofag pada area jejas menandakan bahwa fase inflamasi hampir berakhir dan fase proliferasi dimulai. Makrofag berada di area jejas pada fase inflamasi sampai dengan fase penyembuhan luka berakhir namun dalam jumlah yang sedikit ${ }^{28}$ dan makrofag berfungsi menginisiasi fase proliferatif dengan melepaskan sitokin antiinflamasi serta memulai pembentukan jaringan dengan menghasilkan faktor pertumbuhan $(\text { TGF- } \beta)^{26}$

Hasil penelitian menunjukkan rerata jumlah infiltrasi sel makrofag pada kelompok perlakuan lebih sedikit dibandingkan kelompok kontrol pada setiap waktu pengamatan. Hal ini kemungkinan karena aktivitas eugenol yang dapat menurunkan jumlah sitokin seperti TNF- $\alpha$ interferon (IFN- $\gamma$ ), dan tumour growth factor TGF- $\beta{ }^{14}$ Aktivitas eugenol yang menurunkan jumlah TGF- $\beta$ dan IFN-y kemungkinan akan menurunkan jumlah monosit ke area jejas dan menurunkan jumlah monosit yang berdiferensiasi menjadi makrofag pada area jejas.

Pada penelitian ini, selain jumlah infiltrasi netrofil dan makrofag, jumlah infiltrasi limfosit juga diamati. Hasil penelitian menunjukkan bahwa pada hari ke-1 sudah ditemukan adanya limfosit. Hal ini disebabkan karena pada jaringan ekstraseluler terdapat sel limfosit tissue-resident yang berfungsi mengontrol populasi myeloid tissue-resident, mengontrol respon sel $\mathrm{T}$, dan memodulasi proses nonimunologis misalnya meningkatkan angiogenesis. ${ }^{28}$ Limfosit masuk ke area jejas selama fase inflamasi (lebih dari 72 jam pasca jejas) karena adanya kemoatraktan berupa interleukin-1 (IL-1) yang dihasilkan oleh makrofag. ${ }^{27}$ Limfosit teraktivasi oleh interaksi dengan makrofag yang menyajikan fragmen antigen pada permukaan selnya. Limfosit teraktivasi kemudian menghasilkan berbagai mediator, termasuk IFN- $\gamma$, suatu sitokin penstimulasi utama untuk mengaktivasi makrofag. Makrofag teraktivasi selanjutnya melepaskan IL-1 dan TNF, kemudian mengaktivasi limfosit. ${ }^{16}$

Pada hari ke-3 dan hari ke- 5 rerata jumlah infiltrasi limfosit kelompok perlakuan lebih sedikit dibandingkan kelompok kontrol. Hal ini kemungkinan karena eugenol dapat menurunkan sekresi IL-1 oleh makrofag sebagai kemoatraktan bagi limfosit dan TNF sebagai pengaktivasi limfosit, sehingga akan menurunkan infiltrasi limfosit ke area jejas. ${ }^{13,14,30}$ Pada hari ke-5 rerata jumlah limfosit mencapai puncaknya, hal ini sesuai dengan Regal dan Barbu ${ }^{29}$ yang menyebutkan bahwa limfosit tampak dalam jumlah yang signifikan sekitar hari ke- 5 setelah jejas. Pada hari ke-7 dan hari ke-14 rerata jumlah infiltrasi limfosit kedua kelompok menurun. Hal ini sesuai dengan Larjava ${ }^{31}$ yang menyebutkan bahwa limfosit pada area jejas secara signifikan menurun pada hari ke-7 pasca jejas. 


\section{KESIMPULAN}

Pemberian eugenol dapat menurunkan jumlah sel inflamasi (netrofil, makrofag dan limfosit) pada pulpa gigi tikus Sprague Dawley yang mengalami inflamasi. Perlu dilakukan penelitian lebih lanjut untuk mengetahui mekanisme antiinflamasi eugenol pada pulpa gigi terinflamasi dengan meneliti kadar IL-1 dan TNF- $\alpha$ dan untuk mengetahui dosis optimal eugenol sebagai antiinflamasi pada pulpa gigi.

\section{UCAPAN TERIMAKASIH}

Peneliti mengucapkan terima kasih kepada Dekan FKG UGM beserta jajarannya, Pengelola Program Studi S-2 IImu Kedokteran Gigi FKG UGM, Kepala Departemen Konservasi Gigi FKG UGM, Kepala LPPT UGM dan Kepala Laboratorium Histologi FK UGM beserta staf yang telah memberikan fasilitas dan membantu pelaksanaan penelitian ini.

\section{DAFTAR PUSTAKA}

1. Walton RE, Torabinejad M. Prinsip dan praktik ilmu endodonsia terj. Edisi 3. Penerbit Buku Jakarta: Kedokteran EGC; 2008.

2. Mjar IA. Pulp-dentin biology in restorative dentistry. Chicago: Quintessence Publishing Co.Inc.; 2002.

3. Dondy. Standard Operating Procedure Poli Gigi di Puskesmas [Internet]. 2009 [diakses 8 September 2014]. http://www.scribd.com/ doc/16732277/SOP-poli-gigi-puskesmas.

4. Chen G, Sung Po-Ta. Gingival and localized alveolar bone necrosis related to the use of arsenic trioxide paste- two case reports. J Form Med Assoc. 2014; 113(3): 187 - 190.

5. Garip H, Salih IM, Sener BC, G $\square$ ker K, Garip $\mathrm{Y}$. Management of arsenic trioxide necrosis in the maxilla. JOE. 2004; 30(10): $732-736$.

6. Özmeriç N. Localized alveolar bone necrosis following the use of an arsenical paste: a case report. Int Endod J. 2002; 35(3): 295 - 299.
7. Dumlu A, Yalcinkaya S, Olgac V, Güvercin M. Osteomyelitis due to arsenic trioxide use for tooth devitalization. Int Endod J. 2007; 40(4): $317-322$.

8. Departemen Kesehatan RI. Pedoman pengobatan dasar di Puskesmas 2007, Jakarta: Direktorat Jenderal Bina Kefarmasian Departemen Kesehatan RI; 2008.

9. Tronstad L. Clinical endodontology: a textbook $2^{\text {nd }}$ ed. Stuttgart :Thieme; 2003.

10. Javdani M, Nikousefat $Z$. Research opinion in animal and veterinary science. Res Op Anim Vet Sci. 2012; 2(2): 141 - 144.

11. Chung $\mathrm{G}$, Oh SB. Eugenol as local anesthetic, dalam natural products, Editor: Ramawat KB, Mérillon JM. Berlin: Springer Berlin Heidelberg; 2013.

12. Magalhães $C B$, Riva $D R$, DePaula LJ, Brando-Lima A, Koatz VL, Leal-Cardoso JH, Zin WA, Faffe DS. In vivo anti-inflammatory action of eugenol on lipopolysaccharideinduced lung injury. J App Phys. 2010; 108(4): $845-851$.

13. Grespan R, Paludo M, Lemos P, Barbosa CP, Bersani-Amado, Dalalio MM, Cuman RK. Antiarthritic effect of eugenol on collagen-induced arthritis experimental model. Biol Pharm Bulletin. 2012; 35(10): 1818 - 1820.

14. Ingle $\mathrm{JI}$, Bakland LK. Endodontics $5^{\text {th }}$ ed. USA: PMPH; 2002.

15. Kumar V, Abbas AK, Fausto N, Mitchell R. Robbins basic pathology $8^{\text {th }}$ ed. China: Saunders Elsevier; 2010.

16. Hargreaves KM, Berman LH. Cohen's pathways of the pulp $11^{\text {th }}$ ed. Missouri: Elsevier; 2011.

17. Feng Mei Yu, Yamaza T, Atsuta I, Danjo A, Yamashita Y, Kido MA, Goto M, Akamine A, Tanaka T. Sequential expression of endothelial nitric oxide synthase, inducible nitric oxide synthase, and nitrotyrosine in odontoblasts and pulp cells during dentin repair after tooth preparation in rat molars.Cell Tissue Res. 2007; 328: 117 - 127. 
18. Roitt IM. Essential immunology $8^{\text {th }}$ Ed. Jakarta: Widya Medika; 2002.

19. Kolaczkowska E, Kubes P. Neutrophil recruitment and function in health and inflammation. Nature Reviews Immun. 2013; 13(3): $159-175$.

20. Kumar V, Abbas A, Fausto N. Robbins and Cotran, Pathologic basis of disease $8^{\text {th }} \mathrm{Ed}$. Philadelphia: Saunders: 2006.

21. Levin LG, Rudd A, Bletsa A, Reisner $H$. Expression of IL-8 by cells of the odontoblast layer in vitro. Eur J Oral Sci.1999; 107(2): 131 $-137$.

22. Gensel JC, Zhang B. Macrophage activation and its role in repair and pathology after spinal cord injury. Brain Res. 2015; 1619: 1 - 11.

23. Gehrig SJ, Wilmann DE. Foundation of periodontics for the dental hygienist. Illinois: Wolter Kluwer; 2008.

24. Luo HR, Loison F. Constitutive neutrophil apoptosis: mechanism and regulation. American J Hem. 2008; 83(4): 288 - 295.

25. Velnar T, Bailey T, Smrkolj V. The wound healing process: an overview of the cellular and molecular mechanisms. J Int Med Res. 2009; 37: 1528 - 1542.

26. Roy S, Bagchi D, Raychaudhuri SP. Chronic inflammation: molecular pathophysiology, nutritional and therapeutic interventions. New York: CRC Press; 2013.

27. Fitridge R, Thompson M. Mechanism of vascular disease: a reference book for vascular specialists. Adelaide: The Barr Smith Press; 2011.

28. Burzyn D, Benoist C, Mathis D. Regulatory $T$ cells in nonlymphoid tissues. Nature Immun. 2013; 14; 1007 - 1013.

29. Regan MC, Barbul A. The cellular biology of wound healing [Internet]. 2015 [diakses 12 November 2015]. www.neuro.ki.se/neuro/ KK2/Jimmy_GoogleCACHE1.html.

30. Raja MRC, Srinivasan V, Selvaraj S, Mahapatra SK. Versatile and synergetic potential of eugenol: a review. Pharmaceutica Analytica Acta.2015; 6: 367.

31. Larjava $\mathrm{H}$. Oral wound healing: cell biology and clinical management. United Kingdom: John Wiley and Sons Inc; 2012. 